\title{
Assessing far-field effects of terrigenous sediment loading in the coastal marine environment
}

\author{
Andrew M. Lohrer*, Judi E. Hewitt, Simon F. Thrush \\ National Institute of Water \& Atmospheric Research, PO Box 11-115, Hillcrest, Hamilton, New Zealand
}

\begin{abstract}
Major rain events erode coastal catchments, and muddy plumes of terrigenous sediment can extend far offshore. Surface waters gradually clear as terrigenous sediments sink, although nearbed turbidity may remain high due to resuspension by waves and tides. This may adversely affect large suspension-feeding benthic epifauna, structurally and functionally important organisms in coastal marine systems, by clogging their filtration structures and decreasing their feeding efficiency. While terrigenous sediment concentrations likely decrease with distance from the coast, sensitivities of suspension feeders to this stressor may increase. We tested this hypothesis using controlled additions of terrigenous sediment at estuarine and coastal sites in northern New Zealand. None of the large, solitary suspension feeders (pinnid bivalves Atrina zelandica, sponges Aaptos spp., and ascidians Styela plicata) were completely buried or killed by experimental deposition of terrigenous sediment. However, after living in the deposits for $3 \mathrm{wk}$, the condition of all 3 taxa declined relative to controls, and clearance rates of A. zelandica and Aaptos spp. were reduced (averaging about $40 \%$ less). A. zelandica outside the estuary (Site MI, coarse ambient sediment) were more sensitive to terrigenous material than A. zelandica inside the harbour (Site TK, fine ambient sediment), which was probably related to the greater background suspended sediment concentrations at TK to which the A. zelandica were accustomed. Impacts to large, structure-forming species such as A. zelandica, Aaptos spp., and $S$. plicata may eventually affect ecosystem structure and function, particularly if the frequency or magnitude of terrigenous sediment loading and resuspension increases.
\end{abstract}

KEY WORDS: Terrigenous sediment deposition · Suspension feeders · Condition · Clearance rates · Sponges $\cdot$ Ascidians $\cdot$ Pinnidae

Resale or republication not permitted without written consent of the publisher

\section{INTRODUCTION}

Throughout the Pacific Rim, the regime of terrigenous sediment loading has increased in modern times due to human activities that increase the likelihood of soil erosion in coastal catchments (e.g. logging, farming of livestock, road building, construction excavations), and terrigenous sediment is now a widely recognized disturbance agent in nearshore estuarine and marine environments (GESAMP 1994, Airoldi 2003, Thrush et al. 2004). Deposits of terrigenous sediment are known to smother and kill small marine infauna (McKnight 1969, Kranz 1974, Peterson 1985), but smothering is less likely for large suspension feeding taxa that extend 5 to $15 \mathrm{~cm}$ above the sedimentwater interface. Nevertheless, turbid river plumes extend across vast areas of continental shelf (Foster \& Carter 1997, Wheatcroft et al. 1997, Wheatcroft \& Borgeld 2000), and increased concentrations of inedible particles and the clogging of the filtration apparatus could impact the condition and growth of large suspension feeders over broad spatial scales (Ellis et al. 2002). Furthermore, waves and currents may resuspend freshly deposited fine-grained terrigenous sediments, extending the temporal scale of elevated near-bed turbidity.

Along with the spatial and temporal scales of stress magnitude, the sensitivities of suspension feeders to this stressor are important to characterize. For example, diminishing terrigenous sediment concentrations with increasing distance from a river mouth may be partially offset by increased animal sensitivities over 
the same gradient, extending the spatial domain of significant ecological effects. We tested the hypothesis that suspension feeders adapted to high suspended sediment loads in naturally turbid areas (e.g. estuaries) will be less affected by terrigenous sediment than conspecifics living offshore in clearer coastal waters.

\section{MATERIALS AND METHODS}

To assess the potential far field effects of terrigenous sediment loading we controlled stress magnitude in an estuary and at an offshore coastal site, and measured the responses of suspension feeders in each habitat type $3 \mathrm{wk}$ after the experimental terrigenous sedimentation event. The coastal site, MI, was located next to a small island $\left(36^{\circ} 28.290^{\prime} \mathrm{S}, 174^{\circ} 48.363^{\prime} \mathrm{E}\right)$ and had coarse-grained sediments ( $4 \%$ silt-clay, $65 \%$ medium sands or larger), low suspended sediment loads ( $<1 \mathrm{mg}$ $\mathrm{l}^{-1}$ ), and weak tidal current. The estuarine site, TK, was located inside Mahurangi Harbour (36 29.832' S, $\left.174^{\circ} 43.626^{\prime} \mathrm{E}\right)$ and had fine-grained sediments $(18 \%$ silt-clay, $8 \%$ medium sands or larger). Suspended sediment loads were high at TK (regularly 5 to $10 \mathrm{mg} \mathrm{l}^{-1}$ ), and tidal currents were strong (reaching $28 \mathrm{~cm} \mathrm{~s}^{-1}$ $0.5 \mathrm{~m}$ above the bed on spring tides).

There were several large suspension feeding taxa present at each study site and the pinnid bivalves Atrina zelandica were common at both. The A. zelandica at TK were often covered with soft coral colonies (Alcyonium auranticum), whereas the ones at MI were generally free of large epibionts. The other large suspension feeders (golf-ball sponges Aaptos rosacea and Aaptos globosum, and solitary ascidians Styela plicata) were slightly more common at the MI site and collectively contributed to habitat heterogeneity, although each species was rare $\left(<1\right.$ ind per $\left.10 \mathrm{~m}^{2}\right)$.

Areas of seafloor at each site ( $6 \mathrm{~m}$ depth) were exposed to differing amounts of terrigenous sediment as 2 distinct experimental treatments (four $2 \mathrm{~m}^{2}$ plots treatment $^{-1}$ site $^{-1}$ ). A full description of terrigenous sediment application is presented in Lohrer et al. (2006). To summarise, $1 \mathrm{~m}^{3}$ of soil from the local catchment was collected and mixed with coastal seawater. The sediment-seawater mixture was squirted into large plastic enclosures that were anchored to the seabed by weighted aluminium rings (diameter $=1.6 \mathrm{~m}$ ). The rings and plastic enclosures were left in place for $\sim 2 \mathrm{~h}$ to allow the terrigenous sediment to settle out. The thinner depositional treatment received $24 \mathrm{l}$ of the sediment-seawater mixture, whereas the thicker plots received 561 , resulting in deposits of approximately 10 and $20 \mathrm{~mm}$ thickness respectively. Control areas (to which no sediment was added) were also recognized. Hereafter, our 3 treatments will be referenced as 'thin', 'thick', and 'control'.
Pulsed sediment loading and event-driven deposits of up to $100 \mathrm{~mm}$ thickness occur in landslide prone coastal areas such as those existing in New Zealand and in other Pacific Rim locations (Shaffer \& Parks 1994, Konar \& Roberts 1996, Wheatcroft et al. 1997, Thrush et al. 2004), so the experimental terrigenous deposits of approximately 10 and $20 \mathrm{~mm}$ were not unreasonable. Although the experimental terrigenous deposits slowly decreased in thickness and became covered with ambient marine sediments over time, terrigenous material (with its distinctive yellow-orange colouration) remained visible in thin and thick plots at both sites for about 1 mo.

Four DOBIE (NIWA Instrument Systems) wave gauges were placed on the seabed at each site to quantify significant wave height $\left(H_{\text {sig }}\right)$ and the penetration of wave energy to the seabed (orbital bed velocity, $U_{\text {sigb) }}$ ). Data bursts $(5 \mathrm{~Hz})$ of 7 min were recorded every $20 \mathrm{~min}$ for about 1 mo (during the experiment), and data from bursts were averaged during analysis. In addition to wave information, DOBIEs record water depth, thus providing timestamped tide information. Optical backscatter sensors (OBS) attached to each DOBIE yielded suspended sediment concentrations (SSC) $\sim 15 \mathrm{~cm}$ above the seabed. Calibrations of each OBS with sediments collected from the site of deployment allowed us to translate the electrical voltages into suspended sediment concentrations (mg sediment $\mathrm{l}^{-1}$ seawater).

We exposed large suspension feeders (protruding a minimum of $50 \mathrm{~mm}$ above the sediment-water interface) to terrigenous sediment at both sites and quantified physical variables at the seabed in order to relate physiological changes in the animals to the magnitude of terrigenous sediment deposition (controls vs. the 2 treatments) and ambient levels of SSC (from the OBS). Our objective was to measure condition, feeding rate, and oxygen consumption rate of all 3 species in all treatment $\times$ site combinations. However, this was only possible for Atrina zelandica, which was sufficiently abundant at both sites (averaging 1 to 4 ind. plot $^{-1}$ site $^{-1}$ ). Responses of Aaptos spp. were assessed at just 1 site (MI), and the transplantation of sponges from a nearby site (called Iris Shoal) was necessary to ensure that enough sponges were present in treated plots. For Styela plicata, transplants were not feasible, and we were only able to assess condition. Three weeks after terrigenous sediment application (13 March 2003), animals from control areas and treated plots were collected from the field. All tests involving live suspension feeders were started within $24 \mathrm{~h}$ of collection.

Condition. Tissue weight, corrected for animal size, serves as an index of condition in experiments of short duration (Roper et al. 1991, Hewitt \& Pilditch 2004). Thus, dry flesh weights were measured and condition values were calculated by dividing dry flesh weights by dry shell weight (Atrina zelandica), wet body diameter 
(Aaptos spp.), or wet displacement volume (Styela plicata). The dry flesh weight of suspension feeders was measured after drying at $60^{\circ} \mathrm{C}$ for $72 \mathrm{~h}$. For A. zelandica and Aaptos spp., 3 animals per treatment were measured. For S. plicata, 1 to 3 animals per treatment were pooled and measured, depending on the number recovered from the experimental plots.

Clearance rate. Resuspended terrigenous sediment may clog the feeding structures of large suspension feeders, reducing their ability to utilise food particles present in the water column. To address this hypothesis, study animals $(\mathrm{n}=3$ ) were placed individually into $5 \mathrm{l}$ plastic containers filled with freshly collected coastal seawater. The seawater had ambient concentrations of phytoplankton and other solids, but nothing else was added. Total suspended solid (TSS) concentrations were measured at the beginning of the experiment and $1 \mathrm{~h}$ later by filtering the seawater onto preweighed GFC filters and reweighing the filters after drying for $48 \mathrm{~h}$ at $60^{\circ} \mathrm{C}$. The difference in TSS concentration at the beginning and end of the experiment yielded clearance rates $\left(\mathrm{CR}, \mathrm{ml} \mathrm{min} \mathrm{min}^{-1}\right)$, which were calculated in the following way:

$$
\mathrm{CR}=\frac{\left(\mathrm{TSS}_{\text {beginning }}-\mathrm{TSS}_{\text {end }}\right) V}{\mathrm{TSS}_{\text {beginning }} T}
$$

where $V=$ volume of water in $\mathrm{ml}$, and $T=$ time in min. $\mathrm{CR}$ is thus the volume of water cleared by an animal per unit time. In these experiments we used Atrina zelandica from all plots at each site and Aaptos spp. from plots at MI only. The volume of water cleared was standardized for each species (to a $9 \mathrm{~g}$ dry weight for $A$. zelandica and to an $11.8 \mathrm{~g}$ dry weight for Aaptos spp.) by dividing the clearance rate by the dry flesh weight of the individual and multiplying by the standard weight.

Recall that we transplanted sponges to MI from a donor site called Iris Shoal. To better understand the speed of response to terrigenous sediment exposure, and to characterise the effects of the transplantation process itself, we performed one additional clearance rate experiment using Aaptos spp. collected directly from Iris Shoal. As previously, animals were placed individually into containers filled with coastal seawater. This time, however, the containers were then dosed with low or high concentrations of terrigenous sediment (from the same batch of sediment and corresponding to the thin and thick field treatments). Controls of seawater only were run simultaneously.

Oxygen consumption. To measure oxygen consumption rates, Atrina zelandica and Aaptos spp. were individually placed into sealed, stirred respiration chambers ( 51 volume). The chambers were filled with unfiltered coastal seawater and maintained at $21^{\circ} \mathrm{C}$ in darkness. Again, animals exposed to each of the field treatments (control, thin, and thick) were used in the trials. Water samples were collected at timed intervals in order to measure dissolved oxygen concentrations. Decreasing oxygen consumption signals physiological stress, as it indicates reduced activity during an environmental challenge (i.e. the animals try to isolate their tissues from the stressor and wait until the challenge ends).

Statistical analysis. We tested for experimental effects using 1-way ANOVAs or Kruskal-Wallis tests for each site separately. Our a priori predictions of sitedependent response (due to varying background SSC and hydrodynamics) justified the separate site analyses. When overall significance was detected $(p<0.05)$, post hoc comparisons (paired tests with a Bonferroni adjustment) were used to determine the significance of differences between treatments.

\section{RESULTS}

Spring tides and calm weather conditions prevailed during the first part of the experiment. The average significant $H_{\text {sig }}$ was below $5 \mathrm{~cm}$ at MI and was almost nil inside Mahurangi Harbour at Site TK. Energy from waves of this size essentially did not penetrate to the bed at either site $\left(U_{\text {sigb }}\right.$ values $\left.<2.5 \mathrm{~cm} \mathrm{~s}^{-1}\right)$. Site MI had almost no measurable suspended sediment for the first week of the experiment.

Diving visibility was greatly reduced during low tide in Mahurangi Harbour, and the DOBIE-OBSs at TK registered tidally correlated changes in SSC. Water turbidity peaked at low tide at this site, with SSC values exceeding $10 \mathrm{mg} \mathrm{l}^{-1}$ on many occasions. At high tide, when coastal marine waters flooded the harbour, SSC values generally dropped to near zero. A single turbidity peak centred at dead low tide is consistent with the advection of a SSC gradient up and down the estuary with the ebb and flood of tides. Two peaks (centred at mid-ebb and mid-flood, during maximum current flow speeds) would indicate local resuspension of sediments, but such peaks were not evident.

A storm that intensified during Days 7 and 8 produced average $H_{\text {sig }}$ of 15 to $20 \mathrm{~cm}$ at TK. $H_{\text {sig }}$ were generally highest at high tide at this site. $H_{\text {sig }}$ were slightly greater in TK than they were at MI (located on the leeward side of a small island). $U_{\text {sigb }}$ reached $>25 \mathrm{~cm}$ $\mathrm{s}^{-1}$ at Site TK, but was generally $<15 \mathrm{~cm} \mathrm{~s}^{-1}$ at Site MI.

The concentration of suspended sediments increased during the storm at both sites. Because the sediments are coarse at MI, however, there was little fine sediment available for resuspension and transport during the storm, and SSC values peaked at about $20 \mathrm{mg} \mathrm{l}^{-1}$. At Site TK, SSC values reached over $150 \mathrm{mg}$ $\mathrm{l}^{-1}$ during the storm. The tidally driven changes in suspended sediment concentration at TK usually vary 
between 0 and $15 \mathrm{mg} \mathrm{l}^{-1}$, so the storm increased SSC by about an order of magnitude at this site.

\section{Condition}

Across the 3 genera (Atrina, Aaptos, Styela), all animals exhibited highest condition in the control plots, indicating that terrigenous material affects them negatively. Condition of Atrina zelandica was significantly greater in controls than it was in the thick treatments at both sites (Fig. 1). However, at Site MI, the thin treatments were also significantly different from the controls, suggesting that smaller amounts of terrigenous sediment will affect the condition of $A$. zelandica at this site.

The condition of Aaptos spp. collected from Site MI was significantly greater in the control plots than it was in the thin and thick terrigenous sediment treatments (Fig. 1). The condition of control sponges from Site MI did not differ from the condition of sponges at the donor site, Iris Shoal, indicating that the transplantation of sponges did not harm these animals.

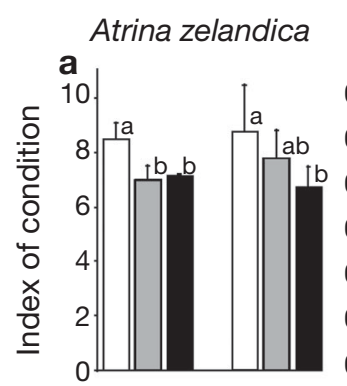

\section{Aaptos spp.}
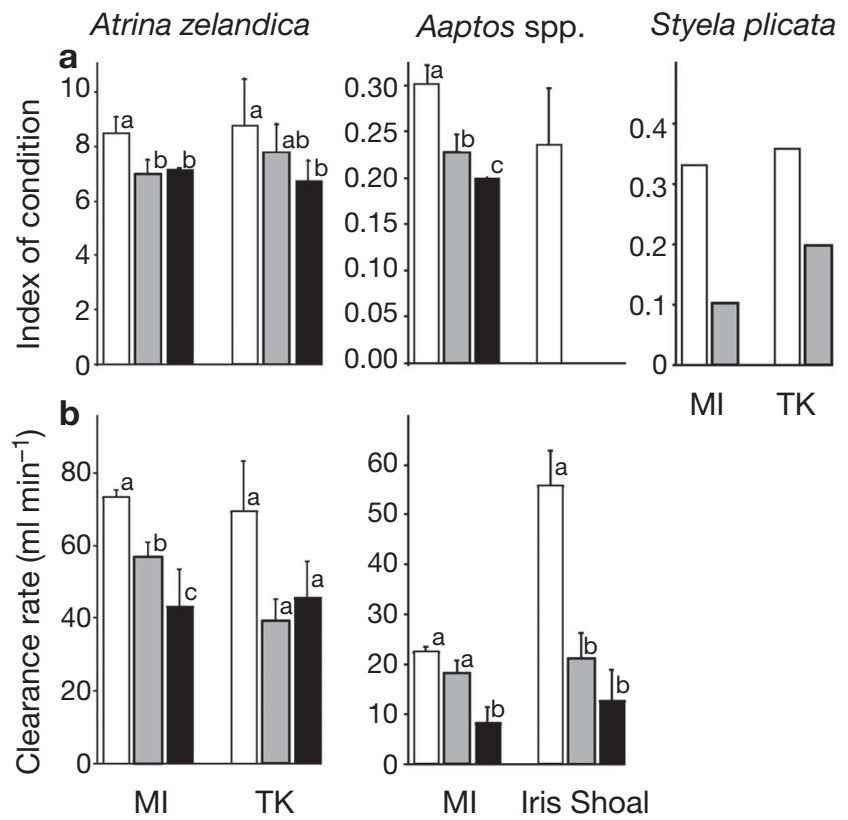

Fig. 1. Atrina zelandica, Aaptos spp., and Styela plicata. (a) Condition and (b) clearance rates for large suspension feeders exposed to terrigenous sediment. White bars: controls; grey and black bars: thin and thick sediment treatments, respectively. The suspension feeders were exposed to treatments for $22 \mathrm{~d}$ in situ at coastal (MI) and estuarine (TK) sites before measurements were made. Iris Shoal was the donor site from which Aaptos spp. were originally transplanted (i.e. the sponges were not exposed to terrigenous sediment until the laboratory trials commenced). Data are means +1 SE (except for $S$. plicata which was measured in aggregate). Letters atop bars indicate results of post-hoc tests; means that share letters are not significantly different from each other
Because the condition of Styela plicata was measured in aggregate, rather than on individuals, the significance of differences between treatments and sites could not be tested. However, the condition of animals collected from within the thin sediment deposits was less than half the level measured for control animals at both sites (Fig. 1). Comparing controls, the condition of S. plicata was similar at both sites.

\section{Clearance rates}

Clearance rates of both Atrina zelandica and Aaptos spp. were significantly affected by terrigenous sediment deposition. After spending $3 \mathrm{wk}$ in sedimenttreated field plots, A. zelandica and Aaptos spp. were unable to feed as efficiently when placed in natural ambient seawater with no sediments added (Fig. 1).

Atrina zelandica from control plots at MI cleared greater volumes of water than A. zelandica from either of the treated plots at MI. There were also significant differences between animals in the thin and thick terrigenous sediment treatments. Such clear differences were not found for the TK animals, however ( $p<0.10$ for control vs. thin and control vs. thick comparisons).

Similar to Atrina zelandica, Aaptos spp. from control plots at Site MI cleared greater volumes of water than the sponges treated with terrigenous sediment (Fig. 1). Naïve sponges collected from the donor site at Iris Shoal also exhibited a similar clearance rate response, indicating that effects from terrigenous sediment occur rapidly (within $1 \mathrm{~h}$ ) and can last for at least $3 \mathrm{wk}$ following a depositional event in the field.

\section{Oxygen consumption}

Atrina zelandica from controls at Sites MI and TK had higher oxygen consumption rates than those in the

Table 1. Atrina zelandica and Aaptos spp. Oxygen consumption rates of 2 large suspension feeders (pinnid bivalves and golf ball sponges) exposed to 3 field treatments (controls vs. thin and thick terrigenous sediment deposits) at coastal (MI) and estuarine (TK) sites. Measurements were made in the laboratory, in darkness at $21^{\circ} \mathrm{C}$, in unfiltered seawater collected from Kawau Bay. Data are means $\pm 1 \mathrm{SE}$

\begin{tabular}{|c|c|c|c|}
\hline \multirow[t]{3}{*}{ Treatment } & \multicolumn{3}{|c|}{ Oxygen consumption rate $\left(\mathrm{mg} \mathrm{O}_{2} \mathrm{l}^{-1} \mathrm{~h}^{-1}\right)$} \\
\hline & \multicolumn{2}{|c|}{ A. zelandica } & \multirow{2}{*}{$\begin{array}{c}\text { Aaptos spp } \\
\text { at MI }\end{array}$} \\
\hline & at MI & at TK & \\
\hline Control & $2.1 \pm 0.3$ & $1.1 \pm 0.0$ & $2.3 \pm 0.1$ \\
\hline Thin & $1.9 \pm 0.1$ & $1.0 \pm 0.2$ & $2.0 \pm 0.6$ \\
\hline Thick & $1.2 \pm 0.2$ & $0.6 \pm 0.0$ & $1.9 \pm 0.0$ \\
\hline
\end{tabular}


thick sediment treatments (Table 1). The Aaptos spp. from control plots at MI also had higher oxygen consumption than the sponges exposed to thick sediment deposits. Similar trends were apparent for controls versus thin sediment deposits, though the differences between controls and treatments were smaller $(\mathrm{p}>$ 0.05, all cases).

\section{DISCUSSION}

The large suspension feeders examined during this experiment survived the application of terrigenous sediment, and all were alive 3 wk later. However, several results provided evidence of physiological harm, indicating the potential for broader spatial scale effects. Most notably, indices of condition were significantly lower for animals exposed to terrigenous sediment, and clearance rates suggested that feeding capacity (and thus potentially scope for growth) was impaired by terrigenous sediment.

This information builds on previous studies that have demonstrated the sensitivity of Atrina zelandica to gradients of suspended sediment concentrations in Mahurangi Harbour (Ellis et al. 2002, Hewitt \& Pilditch 2004). A. zelandica are large organisms that affect numerous benthic processes, from near-bed hydrodynamics to sediment biogeochemistry and nutrient budgets (Green et al. 1998, Nikora et al. 2001, Gibbs et al. 2005, Hewitt et al. 2006). A. zelandica also has an important facilitating effect on surrounding macrofaunal communities (Cummings et al. 1998, Cummings et al. 2001, Norkko et al. 2001, Hewitt et al. 2002). Reductions in condition and feeding that translate to lower growth and reproductive fitness would tend to reduce $A$. zelandica populations over longer time scales, particularly if terrigenous deposition events of the magnitude we simulated are chronic, rather than isolated, or occur at critical periods in the reproductive/life cycle.

The response of Atrina zelandica to elevated suspended sediment concentration is thought to be partly dependent on environmental history (Hewitt \& Pilditch 2004). Ambient bottom water at TK was much more turbid than that at MI, as indicated by the 4 DOBIE-OBSs measuring suspended sediment concentrations at each site. Thus, even though the same quantities of the same terrigenous material were applied at each site, the stress to the large suspension feeding taxa may have differed between sites. That is, for the TK suspension feeders living in an environment with high turbidity, experimental increases in sediment loading may have been proportionately small, relative to the MI animals that live in clearer water. The responses we measured exhibited the same pattern: TK suspension feeders were less sensitive to the experimental treatments than the animals from Site MI.

In this experiment, Atrina zelandica, Aaptos spp. and Styela plicata were exposed to greatly elevated concentrations of suspended terrigenous sediment for a very limited period of time (1 to $2 \mathrm{~h}$, during deposition). Although the terrigenous deposits had a watery consistency on Day 1 and seemed prone to erosion (relative to compacted, consolidated sediments), none of our personal observations suggested massive terrigenous sediment resuspension on Day 1 or afterwards. The oceanographic sensors, which were positioned to detect massive resuspension, did not indicate any differences in SSC between treatments and controls. Thus, the large suspension feeders in treated plots were sensitive to (1) the initial pulse of terrigenous sediment, despite $3 \mathrm{wk}$ for recovery and depuration, or (2) very low levels of terrigenous sediment being resuspended from plots during the experiment. Small amounts of terrigenous sediment have produced significant sublethal effects in other studies (Cummings \& Thrush 2004, Lohrer et al. 2004), and evidence is mounting that terrigenous sediment is a major environmental stressor in marine and estuarine systems (Thrush et al. 2004).

Terrigenous sediment loading has increased in many Pacific Rim estuaries, and the transport of fine terrigenous materials offshore is well documented by seabed measurements (see Wheatcroft 2000) and satellite imagery (see Thrush et al. 2004). Although our predictions of stress magnitude and stress frequency are improving, the sensitivities of animals must be carefully considered when predicting effects of offshore sediment transport. Results of our study imply that large suspension feeders used to clearer marine waters are more sensitive to terrigenous materials, so rare offshore transport events could still be widely problematic. Broadscale declines in the performance of such key species are a significant threat to the functioning of coastal marine ecosystems, and the effects of terrigenous sediment loading may extend further than previously recognised.

Acknowledgements. This research was funded by the Auckland Regional Council (NIWA Project ARC03205), with additional support from the New Zealand Foundation for Research Science and Technology (FRST Contract No. C01X0307). The hard work of numerous divers (R. Budd, R. Liefting, G. Funnell, P. Nicholls, A. Norkko, and C. Lundquist) made the project safe and successful. S. Hatton assisted with laboratory assays, and I. MacDonald calibrated and downloaded oceanographic instruments. Many thanks to B. Thompson and C. Hatton at the ARC for providing resource consents and other assistance during the project. Comments from V. Cummings improved early drafts of this manuscript. 


\section{LITERATURE CITED}

Airoldi L (2003) The effects of sedimentation on rocky coast assemblages. Oceanogr Mar Biol Annu Rev 41:161-236

Cummings VJ, Thrush SF (2004) Behavioural response of juvenile bivalves to terrestrial sediment deposits: implications for post-disturbance recolonisation. Mar Ecol Prog Ser 278:179-191

Cummings VJ, Thrush SF, Hewitt JE, Turner SJ (1998) The influence of the pinnid bivalve Atrina zelandica (Gray) on benthic macroinvertebrate communities in soft-sediment habitats. J Exp Mar Biol Ecol 228:227-240

Cummings VJ, Thrush SF, Hewitt JE, Funnell GA (2001) The variable effect of a large suspension-feeding bivalve on infauna: experimenting in a complex system. Mar Ecol Prog Ser 209:159-175

Ellis JI, Cummings V, Hewitt J, Thrush S, Norkko A (2002) Determining effects of suspended sediment on condition of a suspension feeding bivalve (Atrina zelandica): results of a survey, a laboratory experiment and a field transplant experiment. J Exp Mar Biol Ecol 267:147-174

Foster G, Carter L (1997) Mud sedimentation on the continental shelf at an accretionary margin-Poverty Bay, New Zealand. NZ J Mar Freshw 40:157-173

GESAMP (1994) Anthropogenic influences on sediment discharge to the coastal zone and environmental consequences. UNESCO-TOC, Paris

Gibbs M, Funnell G, Pickmere S, Norkko A, Hewitt J (2005) Benthic nutrient fluxes along an estuarine gradient: influence of the pinnid bivalve Atrina zelandica in summer. Mar Ecol Prog Ser 288:151-164

Green MO, Hewitt JE, Thrush SF (1998) Seabed drag coefficient over natural beds of horse mussels (Atrina zelandica). J Mar Res 56:613-637

Hewitt JE, Pilditch CA (2004) Environmental history and physiological state influence feeding responses of Atrina zelandica to suspended sediment concentrations. J Exp Mar Biol Ecol 306:95-112

Hewitt JE, Thrush SF, Legendre P, Cummings VJ, Norkko A (2002) Integrating heterogeneity across spatial scales: interactions between Atrina zelandica and benthic macrofauna. Mar Ecol Prog Ser 239:115-128

Hewitt J, Thrush S, Gibbs M, Lohrer AM, Norkko A (2006) Indirect effects of Atrina zelandica: linking benthic macrofauna and microphytes to water column nitrogen and oxygen fluxes. J Exp Mar Biol Ecol 330:261-273

Editorial responsibility: John S. Gray (Contributing Editor), Oslo, Norway
Konar B, Roberts C (1996) Large scale landslide effects on two exposed rocky subtidal areas in California. Bot Mar 39: 517-524

Kranz PM (1974) The anastrophic burial of bivalves and its paleoecological significance. J Geol 82:237-265

Lohrer AM, Thrush SF, Hewitt JE, Berkenbusch K, Ahrens M, Cummings VJ (2004) Terrestrially derived sediment: response of marine macrobenthic communities to thin terrigenous deposits. Mar Ecol Prog Ser 273:121-138

Lohrer AM, Thrush SF, Lundquist CJ, Vopel K, Hewitt JE, Nicholls PE (2006) Deposition of terrigenous sediment on subtidal marine macrobenthos: response of two contrasting community types. Mar Ecol Prog Ser 307:115-125

McKnight DG (1969) A recent, possibly catastrophic burial in a marine molluscan community. NZ J Mar Freshw 3: $177-179$

Nikora V, Green MO, Thrush SF, Hume TM (2001) Structure of the internal boundary layer over a patch of horse mussels (Atrina zelandica) in an estuary. J Mar Res 60:121-150

Norkko A, Hewitt JE, Thrush SF, Funnell GA (2001) Benthicpelagic coupling and suspension-feeding bivalves: linking site-specific sediment flux and biodeposition to benthic community structure. Limnol Oceanogr 46:2067-2072

Peterson CH (1985) Patterns of lagoonal bivalve mortality after heavy sedimentation and their paleoecological significance. Paleobiology 11:139-153

Roper DS, Pridmore RD, Cummings VJ, Hewitt JE (1991) Pollution related differences in the condition cycles of Pacific Oysters Crassostrea gigas from Manukau Harbour, New Zealand. Mar Environ Res 31:197-214

Shaffer JA, Parks DS (1994) Seasonal variations in and observations of landslide impacts on the algal composition of a Puget Sound nearshore kept forest. Bot Mar 37:315-323

Thrush SF, Hewitt JE, Cummings VJ, Ellis JI, Hatton C, Lohrer AM, Norkko A (2004) Muddy waters: elevating sediment input to coastal and estuarine habitats. Front Ecol Environ 2:299-306

Wheatcroft RA (2000) Oceanic flood sedimentation: a new perspective. Cont Shelf Res 20:2059-2066

Wheatcroft RA, Borgeld JC (2000) Oceanic flood deposits on the northern California shelf: large-scale distribution and smallscale physical properties. Cont Shelf Res 20:2163-2190

Wheatcroft RA, Sommerfield CK, Drake DE, Borgeld JC, Nittrouer CA (1997) Rapid and widespread dispersal of flood sediment on the northern California margin. Geology 25:163-166

Submitted: June 22, 2005; Accepted: November 8, 2005

Proofs received from author(s): May 22, 2006 